\title{
基于二维矿物材料的RRAM器件实现非马尔可夫链功能
}

周鹏

复旦大学微电子学院, 专用集成电路与系统国家重点实验室, 上海 200433

E-mail: pengzhou@fudan.edu.cn

\section{A non-Markov chain in a single RRAM device made of two-dimensional mineral materials}

Peng Zhou

State Key Laboratory of ASIC and System, School of Microelectronics, Fudan University, Shanghai 200433, China E-mail: pengzhou@fudan.edu.cn

doi: 10.1360/TB-2021-0511

在大数据时代, 各类数据的分析与预测日益重要. 结合 数据历史状态以实现预测, 即数据的非马尔可夫过程 (the non-Markov chain), 更能凸显出大数据分析的优越性. 从算 法上说，非马尔可夫链的下一状态不仅与当前状态相关，还 与上一状态转换到当前状态的路径相关. 相对于马尔可夫链, 非马尔可夫链更接近现实的物理世界, 具有更高的预测准确 度. 此外, 很多物理模型都遵守这一过程, 如与时间相关的脑 神经突触、环境相关的量子纠缠态和热力学过程等. 在传统 的器件结构中, 需通过软件算法方式或大量晶体管和存储器 的集成来实现非马尔可夫过程相关功能, 这导致器件结构复 杂、功耗高等问题. 存储与记忆功能是组成复杂系统的基本 模块, 也是实现算法的基础. 双端阻变存储器 (RRAM) 是近几 十年来兴起的一类存储器件, 因其高集成度、快速开关过 程、与当前半导体工艺兼容等优点受到了研究人员的广泛 关注. RRAM通常由两层导电层夹着中间的活性层的三明治 结构构成, 其中中间的活性层一般为氧化物材料. 在外加电 场的作用下，原本处于高阻态的活性层由于离子迁移、空位 填充等将会在垂直方向上形成导电细丝, 进而转变成低阻态. 这种高低阻态的变化可以被外加电场调控，从而实现阻变存 储与计算功能. 近年来, 随着电子器件集成度的进一步增加, 薄层二维层状材料作为 RRAM的活性层展现出诸多优异特 性, 特别是在未来柔性电子领域等方面.

最近, 清华大学深圳国际研究生院成会明、刘碧录团 队 ${ }^{[1]}$ 基于二维矿物材料云母内部离子的迁移和导电特性构筑
出双端RRAM器件, 并首次通过单一器件实现了非马尔可夫 链功能原型器件的制备. 云母是一种天然层状矿物, 具有矿 产丰富、价格低廉、易于规模化加工制备、环境友好等优 点. 研究人员利用具有纳米级分辨率的导电原子力显微镜探 究云母的电学特性. 电学测试及离子分析结果表明云母内部 的 $\mathrm{K}^{+}$可以沿着电场定向移动，这种离子排布使其在面外方向 具有良好的阻变特性，包括高开关比、可重复性以及长时间 稳定性等 ${ }^{[1]}$. 通过调节外加电场的大小可进一步在该类云母 器件中得到具有不同单/双开关窗口的电流-电压特性(图1), 有利于通过电场调控实现器件的多功能化.

基于此, 研究人员利用云母的内部离子导电特性模拟了 硬件非马尔可夫过程. 他们定义正负电场作为非马尔可夫逻 辑的两种不同激发方式, 以器件在 $1 \mathrm{~V}$ 偏压下的电流大小作 为不同状态. 由于云母中的 $\mathrm{K}^{+}$带有正电荷, 对于不同极性电 场具有不同的响应过程. 与传统的器件集成方式相比, 他们 成功利用单个RRAM器件实现了非马尔可夫功能(图 1) ${ }^{[1]}$. 该 研究为非马尔可夫功能的简易实现提供了一种潜在方案, 对 未来人工智能和大数据算法等领域的发展具有重要意义. 此 外, 研究结果还清晰地表明了离子型矿物二维材料在下一代 阻变器件中的应用前景. 结合“自上而下”规模化剥离制备二 维矿物材料的方法及相应组装技术，有望实现大面积、高质 量二维矿物薄膜材料的低成本、规模化制备, 并进一步大幅 推动矿物类材料在柔性电子器件、新一代神经形态计算技 术和物联网等领域的应用. 
(a)
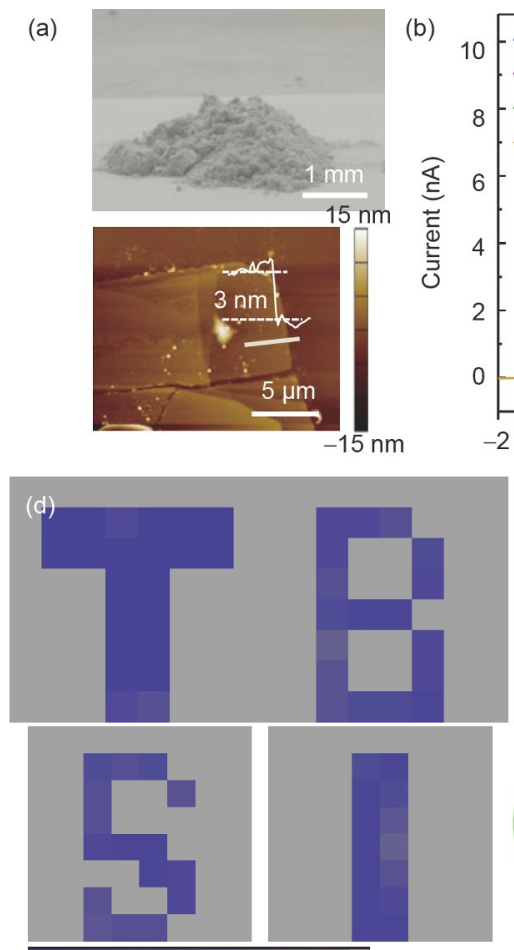

$10^{-4} \mathrm{nA}$

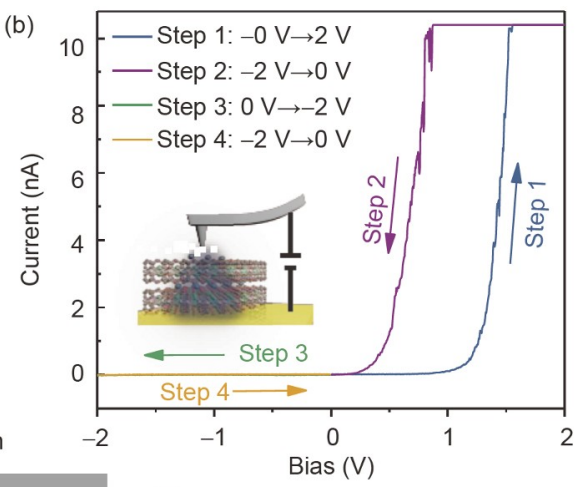

(e)

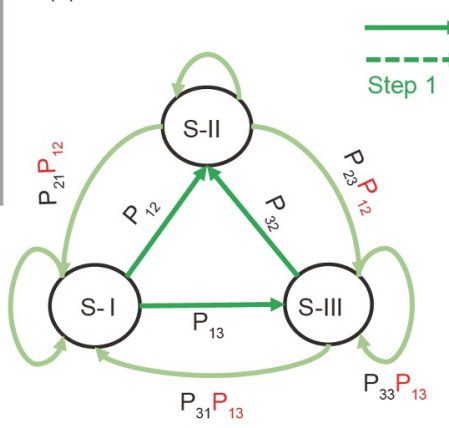

$P_{31} P_{13}$

$\mathrm{P}_{33} \mathrm{P}_{13}$

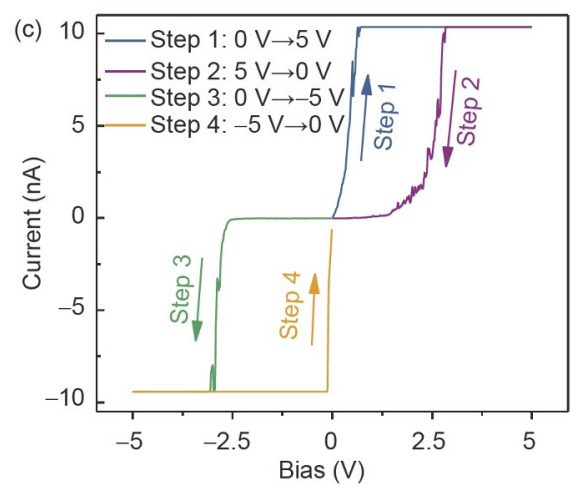

(f)

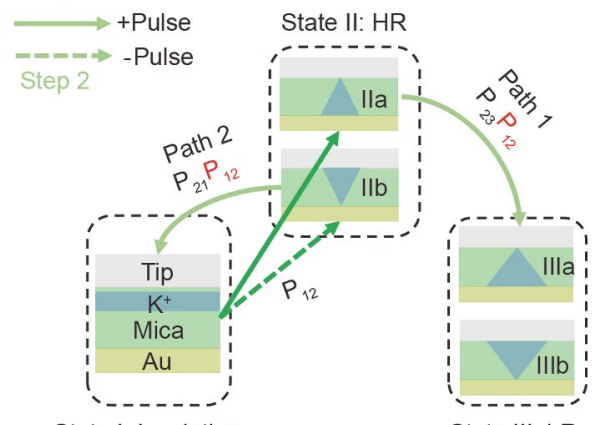

State I: Insulating

图 1 (网络版彩色)(a) 云母矿物的光学照片和二维(2D)云母材料的原子力显微镜图片. (b) 器件在-2 2 V电压下的单窗口阻变行为. (c) 器件在 $-5 \sim 5 \mathrm{~V}$ 电压下的双窗口阻变行为. (d) $8 \times 8$ 阵列二维云母器件在 $1 \mathrm{~V}$ 电压下测试的图案, 此处“T”、“B”、“S”、“I”被提前用 $10 \mathrm{~V}$ 电压激发成开态. 典型的非马尔可夫链(e)和用云母实现的非马尔可夫链(f)示意图. 器件的 3 个不同电阻态定义为: 非马尔可夫链的State I(绝缘态), State II(高阻态) 和State III(低阻态). 这里施加的正负电压分别用实线和虚线标出

Figure 1 (Color online) (a) Optical and atomic force microscope image of 2D mineral mica. (b) RRAM behavior of the device stimulated by a periodic triangular wave voltage with an amplitude of $-2-2 \mathrm{~V}$. (c) RRAM behavior of the device stimulated by a periodic triangular wave voltage with an amplitude of $-5-5 \mathrm{~V}$. (d) Pattern of a device array with $8 \times 8$ positions in $2 \mathrm{D}$ mica measured under $1 \mathrm{~V}$, in which the areas with "T", "B", "S", and "I" patterns were pre-set to be "on" state with a pulse voltage of $10 \mathrm{~V}$. Schematics of (e) a typical non-Markov process and (f) a non-Markov chain achieved by a 2D mica-based device. The three resistance states of the device are defined as State I, State II, and State III, which correspond to the insulating, HR and LR states, respectively. The applied positive and negative pulse voltages are indicated by solid and dotted arrows, respectively

\section{参考文献}

1 Zhang R, Chen W, Teng C, et al. Realization of a non-Markov chain in a single 2D mineral RRAM. Sci Bull, 2021, 66: 1634-1640 